\title{
ET UANSET EGENHÆNDIGT VIDNESBYRD OM GRUNDTVIGS UNGDOM
}

Beskrevet og udgivet af Helge Toldberg.

Takket være en rundelig bevilling fra Statens almindelige Videnskabsfond er det store arbejde med at registrere samtlige håndskrifter i Grundtvig-arkivet på det kgl. bibliotek nu i fuld gang. Hovedformålet er naturligvis at nå til et fuldstændigt overblik over denne den største samling efterladte papirer fra nogen dansk forfatter, herunder også at danne sig et skøn over forholdet mellem trykmanuskripter, udkast til trykte afhandlinger (der i Gr.s tilfælde tit adskiller sig enormt fra de færdige arbejder) og opgivne eller henlagte digte, artikler, optegnelser $\mathrm{m}$. $\mathrm{m}$. Men dertil kommer at en sådan systematisk kulegravning trods tidligere forskeres mere eller mindre sikre instinkt bringer ting for dagen, som er passeret uænset, fordi de ved første øjekast så temmelig uinteressante ud, men som ved et nøjere eftersyn måske ligefrem udfylder huller $\mathrm{i}$ vor viden.

Dette er tilfældet med fasc. 172 b, Om mit Forhold til det antiqvariske Studium, hvis overskrift rimeligvis har forekommet forskerne for speciel til at dække noget epokegørende, og hvis første side er begrænset til det snævert afstukne emne og iøvrigt holdt i bred almindelighed. Man skal blade om for at opdage, at vi her står overfor en rig kilde til åndsmennesket Grundtvigs ungdomsbiografi, der kunne have bekræftet tre af vore aktive Grundtvigforskere i deres metoder eller resultater: William Michelsen $i$ at søge tilblivelsen af Gr.s historiesyn i Udby, Gustav Albeck i at tillægge P. N. Skovgaard æren for at indføre Gr. i den oldislandske litteratur (jf. GrStud 1953 s. 103 ff., der dog må suppleres med at Skovgaard for Gr. var og blev »Mathematiker«), og Niels Kofoed i hans principielle afstandtagen (Grundtvig som selvbiograf s. 12) fra de yngre kilder som »bevidst eller ubevidst fordrejede, - som regel lidt af begge dele«.

En anden ting er at en sammenligning mellem den her behandlede afhandling og den trykte den er udkast til, kunne have givet Kofoed et nyttigt konkret materiale til belysning af hvordan (og måske hvorfor) Gr. omarbejder eller snarere forkorter oplysningerne om sin 
fortid. I det foreliggende tilfælde er det en hensigtsmæssig objektivering af emnet, for at undgå den udtømmende beskrivelse af personlige forudsætninger for hans litterære sysler som samtiden ikke uden grund betragtede som hans skødesynd, selv om det mindre er proportionerne end graden af åbenhjertighed der er ændret. I håndskriftet er der $8^{1 / 3}$ side om forudsætninger og $7^{2 / 3}$ om selve emnet, i den trykte afhandling - Et Par Ord om Oldgrandskning (DV. III. 167-190 - de tre første ord i titlen udeladt i indholdsfortegnelsen, optrykt US. III.512-524, VU. II. 208-220) - 12 sider om personlig baggrund $\left.{ }^{1}\right)$ og 11 om emnets aktuelle problemstilling. Overensstemmelsen i proportion er vigtig også af en anden grund: håndskriftets 4. og sidste ark er fuldskrevet. Det subjektive skøn at det virker afsluttet, finder heri en ydre støtte.

Fælles for afhandlingens trykte og utrykte form er foruden denne tvedeling det ydre skelet $i$ oplysningerne, f. eks. om vennen $P$. N. Skovgaards indflydelse i Gr.s tidlige ungdom, og den principielle indstilling til oldgranskningen. Men anlægget er så forskelligt i de to redaktioner at man må glæde sig over at have et sikkert verbalt bevis for samhørigheden, endda på et af de steder der tydeligst understreger forskellen:

Fasc. 172 b. 4 v. vist nok havde jeg stedse betragtet Valgrind, som hvad den havde været for mig, Dørren til Sagas Tempel, hvor Alter-Tavlen hængde bekrandset med vidnesføre Kiærminder, men deels mærkede jeg, at neppe mange vilde færdes paa den Vei, deels begyndte jeg at indsee, at Dørren forde til to Gemakker, langt mere forskiellige, end jeg hidtil havde ændset: til Eventyrets saavelsom til Historiens,
Danne-Virke III. $177 \mathrm{f}$.

med den levende Indsigt, at Valgrind, hvorigiennem jeg havde seet en Indgang til Historiens Tempel og til Syn af Alter-Tavlen, omkrandset af vidnesføre Kiærminder, at den dog snarere førde ind i Eventyrets DrømmeHald, og at Nordens Saga saalidt som nogen, kunde til Gavns forbinde $\mathrm{Hi}$ storie og Eventyr;

At Gr. aldrig har truffet dispositioner til at trykke afhandlingen i den form den har i fasc. $172 \mathrm{~b}$, fremgår af at han ikke har forsynet den med arknumerering ${ }^{2}$ ), sådan som vi kender den - fortløbende heftevis - fra bevarede dele af trykmanuskriptet til Danne-Virke (f. eks. alle bestanddele i fasc. 173 eller fasc. 172 c, Om Dannefæ og Hittegods, med arknumerering 21-31, DV. IV.65-95). Derimod

1) $\mathrm{Kr}$. Arentzen har dog været opmærksom på den første dels betydning som selvbiografisk aktstykke, og aftrykt den med fyldige noter Baggesen og Oehlenschläger VI (1876). 359-369.

$\left.{ }^{2}\right)$ Den bladnumerering vi her benytter, er tilføjet med blyant i moderne tid. 
findes nummeret 17 på et ikke fuldskrevet enkeltblad - fasc. $172 \mathrm{e}-$ Om Fornjotur og hans $Æ t$, der viser hen til det nærmest følgende bidrag i DV. III, og som særlig bør påkalde vor opmærksomhed, fordi der på fasc. $172 \mathrm{~b}$ som oprindelig, men overstreget overskrift står Om Forniotur ${ }^{3}$ ) og hans Stamtavle. Der synes således at være en dybere sammenhæng mellem de to artikler.

Et skridt nærmere løsningen føres vi af det bevarede trykmanuskript (henlagt i fasc. 268) til DV. III.190-194. Det er et bidrag udefra (det eneste i hele DV., jf. GrStud. 1949.11 og Steen Johansen. Bibliografi. IV.26), et forsøg på tolkning af myten om Norges ældste bebyggelse. Men dette ark er af Gr. numereret 23, mens udkastet fasc. $172 \mathrm{e}$ var numereret 17. Herpå er kun én forklaring mulig: Fornjótr-artiklen har fra begyndelsen skullet stå umiddelbart efter det foregående, store bidrag (Ansgars Eftermæle), men er i sidste øjeblik blevet skubbet frem for at give plads til den antikvarisk-mytologiske selvbesindelse Gr. er blevet drevet til ved den hovedkulds beskæftigelse med et emne indenfor et område han troede for stedse at have vendt ryggen. At det virkelig er kommet bag på ham, fremgår nemlig af en egenhændig - overstreget - redaktionel anmærkning forneden på indlæggets sidste side:

Min Mening herom er vel forlangt, men deels har jeg ingen Lyst til at forekomme Læseren, og deels for Øieblikket ikke Stunder til det Giennemsyn, der forudsættes, naar min Mening ikke skulde staae som en Dom man er uberettiget til at fælde over Ting der ere en naturlig Gienstand for Giætning.

U. A.

Anmærkningen kan kun tydes som en tilkendegivelse af at bidraget udefra fra først af ikke har været velkomment, fordi det drejede Gr.s opmærksomhed $\mathrm{i}$ en anden retning end han for tiden ønskede. Bemærkningen om manglende tid til gennemsyn er ingen tom undskyldning: 1 . hefte var udkommet ${ }^{12 / 7} 1817$, og 2 . fulgte kun 46 dage efter ( ${ }^{27} / 8$, jf. Steen Johansen. Bibliografi. I. 136). Når Gr. skulle kaste sig ud i et virkeligt studium - hvad han faktisk alligevel gjorde -, måtte dette ske $\mathrm{i}$ et forrygende tempo. Heri ligger det sikreste bevis for at fasc. $172 \mathrm{~b}$ er en virkelig førstegrøde, hvor ingen taktiske hensyn har kunnet nå at lægge bånd på Gr.s ytringer.

I stedet for den golde afvisning af beskæftigelse med Fornjótrmyten, rullede Gr. sig ud med en seks siders kommentar, som jeg håber at underkaste en grundigere undersøgelse i en kommende større behandling af Gr.s forhold til den nordiske mytologi, idet vi her finder kimen til hans metodik $\mathrm{i}$ alle senere mytologiske arbejder.

3) Flere rettelser i dette navn. Den angivne form er slutresultatet. 
Hvad der i nærværende sammenhæng har den største interesse, er at han trods sin kølige forhåndsindstilling er blevet fyr og flamme (DV.III.195, en trykfejl rettet):

Det er mig derfor meget kiært, ved Ovenstaaende, at være blevet foranlediget til en Revision af hele Eventyret, og jeg vil da meddele mine Læsere den fuldstændige Stamtavle, som den er at finde i den saakaldte Norges Opdagelse (Fundinn Noregur) og i Thorsten Vikingsons Saga.

Det tør nu betragtes som fastslået at Gr. mod sin vilje er blevet trukket tilbage til nordisk-mytologiske sysler, og ved siden af det konkrete emne har besindet sig på en større principiel sammenhæng, hvor hovedvanskeligheden for ham har været at afbalancere fremstillingen af sit personlige forhold til området. Mens dette dominerer fasc. $172 \mathrm{~b}$ og er fremtrædende uden at være utilbørligt eller afslørende $\mathrm{i}$ den endelige DV-afhandling, findes der et andet udkast Om Oldgrandskning, fasc. $172 \mathrm{a}$ - hvor det er trængt helt ud. Dette fragment, som standser midt $i$ en sætning langt nede på 2. side, er tilsyneladende yngre end fasc. $172 \mathrm{~b}$, der jo oprindelig havde Fornjótroverskrift. Dets samhørighed med de to øvrige tekster er sikret ved en verbal overensstemmelse på et for Gr. så afgørende punkt som i foragten for antikken: »at vi skulde giøre os en Pine og Ere af at løse de saakaldte classiske Nationers Skobaand, og slikke Støvet op under deres Fødder.« At den nøjere ligner DV. III. 169 end første side af fasc. $172 \mathrm{~b}$, er ikke noget absolut sikkert bevis, men nok et sandsynligt tegn, på at den ligger imellem de to. Det fremherskende træk, den konsekvente objektivering, er måske den dybeste grund til at fragmentet så hurtigt blev opgivet, til fordel for en form der stemte med Danne-Virkes helhedspræg i problemstilling, og som typisk for DV-afhandlingerne - tog sit udgangspunkt i Gr.s aktuelle filosofisk-religiøse standpunkt.

Det er et par gange antydet at fasc. $172 \mathrm{~b}$ vinder i biografisk troværdighed ved at virke så uovervejet. Prisen herfor er ganske naturligt blevet at det principielle mytologiske afsnit er tilsvarende svagere, så vagt og alment at det påkalder den største beundring for Gr.s arbejdsomhed og energi at han, på den korte tid der har været undt ham, har fået den rettet op til noget så fremragende som den trykte form, der vidner om en virkelig saglig fordybelse efter de mange års pause. Der er en smuk parallel mellem denne højnelse i det faglige og den for Gr. sjældne selvkritik $i$ omarbejdelsen af hans personalia, i særdeleshed hvor han tilslører hvordan gerningen som historielærer hjalp ham over Asarusen.

På den anden side er det værdifulde ved udkastet, som nedenfor vil blive aftrykt uforkortet, Gr.s uforbeholdne fremstilling af egne 
anliggender, med kritikken af »Høiskolen«, d. v. s. universitetet, og taknemmeligheden mod Skovgaard som kernepunkt. Det er hævet over tvivl at universitetet rent menneskeligt svigtede studenterne, bl.a. ved at gøre ordningen med privatpræceptor, en professor studenterne - i lighed med den i England stadig gældende tutor-ordning - var indskrevet til, illusorisk, idet professoren ikke gad lære studenten at kende, endsige optræde som hans rådgiver. Et lidt yngre vidnesbyrd, Goldschmidts i Hjemløs (1853, II.7), om en student der søger personlig kontakt med sin privatpræceptor og af den utilnærmeliges tjener belæres om sin fejltagelse, kunne have passet på Gr., der sikkert også ville have underskrevet Goldschmidts kommentar:

Men der findes nu engang ved vor videnskabelige Høiskole ingen Tilknytning mellem Lærere og Disciple; Professorernes Liv er ikke helliget Ungdommen uden i Forelæsningstimerne; de have Intet at gjøre med at være Veiledere, at virke umiddelbart med deres Personlighed og Exempel.

At Skovgaard blev Gr. en virkelig privatpræceptor, er vel noget nær den største ros denne kunne give ham, for det betyder at han $\mathrm{i}$ sin vanskeligste tid i ham på én gang fandt et ideal og en opmuntrende ven. I det matematiske har han ikke kunnet følge Skovgaard; men det astronomiske, som dog heller ikke var Gr.s stærke side ${ }^{4}$ ), har vennen indviet ham i oppe i det gamle observatorium på Rundetårn! Og det blev tilskyndelsen i Skovgaards brev der forløste Gr. som nordisk-mytologisk skribent. Indirekte har Skovgaard æren for at han opgav at skrive nordiske fortællinger ${ }^{5}$ ) i Suhms og Samsøes stil eller dramatiske situationer efter skabelonen i sidstnævntes hovedværk Dyveke.

At gerningen som historielærer ved det Schouboeske Institut blev lige så skelsættende som Egeløkke-opholdet, er intetsteds sagt så klart som i nærværende udkast: Gr. måtte opfyldes af begivenhedsforløbet $i$ verdenshistorien med en lige så påtrængende intensitet som hidtil af den nordiske mytologi. Dette er vigtigt for helhedsbedømmelsen af Gr.s virke: mytologi og verdenshistorie var ikke to parallelle baner, men to poler han svingede imellem. Vi må endda tilføje at der var en periode - fra 1809 til 1817 - hvor han slet ikke havde regnet med ny udsving mod den mytologiske pol; han siger udtrykkelig i den trykte afhandling (DV.III.179) at han om

4) Jf. fra Gr.s senere år afhandlingen Den Copernicanske Astronomi som den fjerde Troes-Artikel (i Nordisk Kirke-Tid. 1837, Steen Johansens Bibliogr. nr. 574).

$\left.{ }^{5}\right)$ Jf. Steen Johansens Bibliogr. nr. 26 og 33, og om genren Rubow. Saga og Pastiche (1923). 3-10. 
mytologien »i otte $\mathrm{Aar}^{8}$ ) ei talde, uden stundum i flygtige Vink«. Tidsangivelsen otte år betyder at Gr. sætter punktum ved Optrin af Kæmpelivets Undergang $i$ Nord (1809), et synspunkt der motiverer den krise forud for den religiøse, som både Gustav Albeck og jeg ${ }^{7}$ ) har været inde på, og som sættes i relief af udkastets ord om det forudgående mytologiske syn: »en halvklog, men just derfor ogsaa halvgal Beskuelse af Oldtiden og Modersmaalet!« Dette kan tages til indtægt for min formodning om tre lag i tilblivelsen af Optrin af Norners og Asers Kamp (1811): 1) saga-edda-pastiche, 2) gendigtning af eddakvad i mere middelalderlige strofeformer (antydet APhS.XIX. $162 \mathrm{f}$.), og 3) den egentlig kristelige overarbejdelse med missionsprædikenerne; og det forklarer overgangen til Baggesensk stil i fordømmelsen af det - Gudskelov - nu opgivne nordisk-mytologiske studium i det store digt Expectoratio. Til Læseren i nytårsgaven Idunne (fortale dateret $5 / 121810$, jf. især s. 80 f., delvis cit. Gr. symb. 240 , note 47$)$ :

Med Anger jeg bekænder,

At jeg engang var gal,

I Nordens Gudesal

Jeg gerne vilde spanke,
$\mathrm{Nu}$ er det Gudskelov forbi;

Som al min høie Poesi,

$\mathrm{Nu}$ har jeg min Forstand igen,

Og Gudskelov at selv den kom,

Men foruden mindelserne om opgør på Grundtvigs egen indre front er der - ligesom i afhandlingens trykte form - polemik mod den omverden der er fremturet $\mathrm{i}$ æstetiske eller mytologiske skriverier $\mathrm{i}$ en ånd han ud fra sit 1809-10 tilkæmpede stade må betragte som uforsvarlig, først og fremmest kresen omkring det litterære tidsskrift Athene, hvor Gr. i sommeren 1817 for anden gang følte sig trådt over tæerne, og dermed var blevet mindet om det gamle opgør fra 1814, hvis problem han ud fra sine forudsætninger havde gjort op i titlen på sit svarskrift Skal vi tro paa Gud eller paa Athene? eller om Tro og Fornuft ${ }^{8}$ ). Det nye angreb - i nummeret for juli 1814 (Athene. IX.77-80, delvis citeret Rønning. II. 2.143 f.) - indgik i Peder Hjorts (anonyme) »Reflexioner over Litteraturen«, og var en protest mod Gr.s »Bestræbelser efter at tilintetgiøre sin litteraire Værdi, ja man kunde sige sin hele aandelige Virksomhed«. Det er

6) Den betydningsfulde undtagelse, digtet Thryms Kvide i Kvædlinger (1815), regner jeg med at komme tilbage til i min store undersøgelse af forholdet til den nordiske mytologi.

$\left.{ }^{7}\right)$ Jf. henholdsvis GrStud. 1954. 35 og Grundtvigs symbolverden. 12 (samt Acta Philologica Scandinavica. XIX (1947-49). 162-164).

$\left.{ }^{8}\right)$ Jf. Høirup. Grundtvigs Syn paa Tro og Erkendelse. 107-109. 
på én gang harme over at Gr. underkender sine egne lødige ungdomsværker, kritik af hans ensidige belysning af alt ud fra Lutherdommen, og forkastelse af Gr.s krav på filosofisk kompetence i Danne-Virke-afhandlingerne. Dette sidste, som nok har været mest sårende for Gr. og bestemmende for skældsordet 》Grønskollinger« mod Athenes skribenter, når sin kulmination i følgende affejning:

hvad er vel arrogantere, end at et uphilosophisk Hoved sætter sit »eget Jeg« imod det hele attende Aarhundrede, i hvilket Mænd som Leibnitz, Kant, Fichte, Schelling og mange flere have skrevet og virket? At sund Tænkning er forsvunden af disse Afhandlinger, er vel en overflødig Bemærkning. Den fornemste Slutning er Udraabet: »det er klart.« Men af denne og lignende Paastande er det langt klarere, at der desværre i Grundtvigs Hoved nu er ikke lidet dunkelt.

Redaktøren af Athene var Gr.s tabte ungdomsven Molbech, men det værste irritationsmoment var de unge romantikere, især Hjort og Hauch. Ikke for ingenting blev bladet inkarnationen af alt hvad Gr. følte sig forpligtet til at stå imod. Et udkast til et poetisk opgør (i fasc. 387, af Sv. Grundtvig sandsynlighedsdateret til 1817, trykt PS. IV. 570 f.) med Athene, Menneske-Kundskab, stiller i dialogens form Minerva overfor Gr.s nordiske historiepersonifikation Saga. Det er karakteristisk for Minerva, at hun gør krav på at indbefatte også anden mytisk visdom end den klassiske, og at hendes præster er ved »At forme idealisk det reale« - Gr.s hovedangrebspunkt på romantikken. Mens denne satire blev i Gr.s skuffe, kom hans frontalangreb i 4. hefte af DV. III (udsendt ${ }^{25} / 11$ 1817), der kun bestod af fortalen til hele bindet, og Gr.s første mytologiske digterværk ud fra de ny forudsætninger, Ragna-Roke (optrykt PS. IV. 481-548, analyseret Gr. symb. 79-87). Mens det i læsedramaet mest sker i finter, er der i forordet ingen omsvøb (DV. III. XII):

da ingen Anden vilde begynde fra den rette Ende, kunde jeg ikke længer taale at see paa, hvorledes man, i Athene og i Alt hvad dertil hører, bogstavelig trak Rus med livlige Unger-Svende, som sattes til Bogen, og lode sig lettelig bedaare af høitravende Ord, glimrende Løfter, og borgede PurpurLapper, saa de meende at svømme i Mimers Brønd, naar de stode til Halsen i en Torve-Grav, og ledte der om den evige Idee i Naturens progressive Formationer, fra Ur-Bjerge, som sagt, til Tørve-Moser, fra Seerne paa hine, til dem selv med deres intellectuelle Anskuelse af deres eget indtagende Billede i disse. Jeg har gjort, og skal, med Guds Hjelp, fremdeles giøre, hvad jeg kan, for at tilintetgiøre dette Blændværk, uden at forgribe mig paa det Mindste, som har sin gyldige Grund, hvor ilde det saa end er stædt.

Ordet Blændværk henleder opmærksomheden på det standpunkt Gr. i fasc. $172 \mathrm{~b}$ oplyser at have tilkæmpet sig i sin gerning som historielærer: »at selv ved en christelig Beskuelse var Intet uden 
Blændværk vundet, naar Troen fattedes.« Derfor står Ragna-Roke som et skoleeksempel på den eneste form for digtning Gr. anså for forsvarlig: den der havde sit udspring i kristentro og virkelighed. Ved en tilsyneladende selvforringelse, at stille sig selv op som den ringere digtertype - talentet - mod førsterangsdigterne eller genierne, opnår Gr. at blotte modpartens forfængelighed og samtidig fæstne sit eget standpunkt (DV.III.302):

See derpaa, siger Rygtet $^{9}$ ), skal man skille

Geniet fra det underordnede Talent:

Geniet spiller bare for at spille,

Som og man prænter kun for at faae Prent;

Talentet altid har et Maal i Sigte,

Og veed prosaisk altsaa hvad det vil,

Men hvordan kan man kalde det at digte,

Naar man kun spiller paa hvad der er til?

Det genierne digter på er blændværk, mens mottostroferne, Gr.s egen oversættelse af Helgakviða Hundingsbana II str. 40-41, viser at han selv klarer frisag:

Mon Blændværk det være

Som bæres mig for?

See, Dødninger spore

De springende Heste!

Mon Kæmperne ride

$\mathrm{Nu}$ Ragna-Rok ind,

Hvad heller mon Hjemlov

Er Hildinger givet!
Kald ikke det Blændværk

Som bæres dig for!

End Asken ei falder, Skiøndt Øiet os skuer At spore med Kringle De kneisende Heste; Men Hjemlov en Time Er Hildinger givet.

Citatet ovenfor fra fortalen til DV. III understreger endnu tydeligere end de tekster vi arbejder med, Gr.s uvilje mod den ny arkæologiske - metode, som den unge Chr. Jürgensen Thomsen netop havde indlagt sig så stor fortjeneste ved, at han i december 1816, skønt ikke-akademiker, var udnævnt til sekretær i Oldsagskommissionen; for vel holdt Gr. på erfaringsgyldighed, men ikke på materialistisk udforskning af åndelige værdier. Hermed er samtidig sigtet udadtil med den her behandlede afhandling i alle dens former givet.

Det var ikke mildere blikke Gr. havde tilovers for den anden opgående stjerne $\mathrm{i}$ den nordiske myteforskning, islændingen Finn Magnusen, den første herhjemme til at sætte den indbyrdes sammenligning af religionerne træk for træk, den såkaldte komparative me-

๑) Ј: Steffens i sine forelæsninger, jf. Ejnar Thomsens redegørelse og citat Omkring Oehlenschlägers tyske Quijotiade (1950). $141 \mathrm{f}$. 
tode, i system. Som vi vil se af Gr.s egen udredning, var i hans øjne den egentlige opgave at bestemme helheden $i$ den enkelte religion, og gemme detailsammenligningerne til alle religionerne var helhedsbelyst. Den vidtforgrenede mytevisdom bag Minerva i det opgivne fragment Menneske-Kundskab var en venlig hilsen til Athene-ridderen Finn Magnusen. Jo, også han hørte til laget, idet februarheftet for 1816 (VI. 101-140) havde bragt hans Indledning til Forelæsninger over den ældre Edda's mythiske og ethiske Digte. Da det at være islænding heller ikke var nogen kvalifikation i Gr.s øjne, måtte Finn Magnusen udæske Gr. på så mange punkter at det kunne lokke ham tilbage til aktiv nordisk-mytologisk syssel, bare med de lempelser i forhold til ungdomsårenes som hans ændringer i filosofisk-religiøst standpunkt nødvendiggjorde.

Det var dog nok mindre disse end hans uvilje mod de hjemlige prügelknaber, Magnusen og Thomsen, der i denne omgang kastede ham $\mathrm{i}$ armene på to mænd han i foregående fase ville have forsvoret: Fr. Rühs og A. L. Schlözer. Endnu efter sit egentlige farvel til den nordiske mytologi havde han satiriseret over deres manglende ægte begejstring for denne, samt selve det grundsynspunkt han ved genoptagelsen af mytologien 1817 annekterer som sit eget, jf. andetsteds i den før citerede Expectoratio (Idunne. 86):

Som Rühs og Schløzer kunde jeg

Paatage mig min lærde Mine,

Og paa den slagne Landevei

Dig ret methodisk pine;

Bevise Dig at hele Norden
Med al sin hele Sagaflok, Og Asathor med al sin Torden, Og Freia med sin Kat og Rok Er kun et Ammestuevæsen;

Da det må antages at være Rühs og Schlözer (Rühs er utvivlsom) der medindbefattes hvor der tales om »de Adelungers og Ruhsers og Paarsers« lærdom i en af »glosserne« til Thryms Kvide (Kvædlinger. 442), er det en kolossal omsindelse der er sket overfor mytetolkningen. Som allerede antydet, skyldes det i første række den frafaldne romantikers harme over at andre har videreført den ideologi han selv har afsvoret, og hans uvilje mod kresen omkring Athene. Men en direkte henvisning til Schlözer i det fremmede indlæg i DV kan også have ledt ham på sporet.

Schlözers tolkning af Fornjótr-myten er ikke hans eget værk, men videreførelse af et af svenskeren Ihres resultater, og værket der sigtes til: Schlözers Isländische Litteratur und Geschichte (I, 1773) i virkeligheden en bearbejdet oversættelse af svenskeren, således at Schlözers andel er nogle tillæg samt en mængde - stundom let satiriske noter. I Ihres egen karakteristik af Fundinn Noregr, hovedredaktio- 
nen af Fornjótr-myten (i Flatøbogen, behandlet Ihre-Schlözer s.127f.), betegnes traditionen som en fabel. Nu skal man ikke være blind for at denne tolkning har været Gr. kærkommen, fordi den rammede en pæl gennem den hedenske tradition om Norges ældste bebyggelse nordfr $\mathrm{a}^{10}$ ), som ikke bare nordmanden Schøning men også P. F. Suhm havde accepteret som historisk sandhed. Han kunne derfor allerbedst på dette punkt dele Schlözers begejstring, skønt den var rationalistisk begrundet, nemlig i glæden over at få bugt med noget af det nordiske mytesmederi. Ikke des mindre må det dog antages at han også har fulgt Schlözers henvisning til et andet sted, en note (s. 112) helt for hans egen regning, der bebrejder Ihre at han ikke har draget konsekvensen og aflivet forestillingen om den historiske Odin.

Hos Ihre-Schlözer har Gr. da fundet en ny vej til nordisk mytetolkning: krav om et skarpt skel mellem historie og fabel. Når Rühs er medtaget $\mathrm{i}$ afhandlingens utrykte form, er det sandsynligvis med henblik på hans Geschichte Schwedens (I, 1803), hvor han trækker skel ved Kristendommens indførelse og bryder med de klassiske forfatteres autoritet når de berører forhold vedrørende Norden. Det vigtigste er sagt $i$ de to første paragraffer, det egentlig saglige i $\S 2$ : at mørket i Sveriges og i det hele det høje Nordens historie først spredes efter at en videnskabelig kultur er indført med kristendommen, at man om den ældste tid kun har digteres meget fri behandling af kendsgerninger, og at man, belært af tidligere forskeres vidt forskellige og derfor usikre resultater, skal afvise hvad der er blot og bar hypotese. Det føles som denne $\S 2$ har ligget i Gr.s underbevidsthed da han skrev den sidste, principielle del af fasc. $172 \mathrm{~b}$. At Rühs netop på denne tid har kunnet fænge Gr., er ikke så underligt: hans slagord »unwidersprechlich« er jo Gr.s eget.

Det er heldigt at de indre kriterier entydigt daterer udkastet til juli-august 1817, idet det - både i fasc. 172 a, b og e - drejer sig om noget nær ældste kendte benyttelse af vedkommende papirssort, som ellers navnlig er fremtrædende $\mathrm{i}$ digte og prædikener $\mathrm{m} . \mathrm{m}$. mellem 1820 og $1825^{11}$ ): svært hvidt papir med let grålig til gullig

${ }^{10}$ ) Gr.s fund af og kamp for danskernes hellige afstamning fra Jafet, som den fremtræder i den danske rimkrønike, har jeg gjort rede for GrStud. 1954. 52-60.

${ }^{11}$ ) Jf. Nordisk tidskrift för bok- och biblioteksväsen 1946. $112 \mathrm{ff}$., hvor jeg dog ikke har været opmærksom på at der er to typer af firmaets bikubevandmk., således at navnet $\mathrm{i}$ den xldre står $\mathrm{i}$ en vandret oval, mens det modstående blad mangler dobbeltkryds. Det yngre, her beskrevne vandmk. (dobbeltkrydssiden) findes vist første gang $\mathrm{i}$ et udkast til 1. strofe 
tone, med tydelige længdestreger og tværfibre, samt vandmærke henholdsvis CEJHonig i rektangel under fundament til bikube i våbenskjold og ( $i$ modstående foliohalvark) CEIH under dobbeltkryds. Til yderligere karakteristik skal anføres den i tidsrummet 1811-23 næsten gennemførte ${ }^{12}$ ) mærkning af hvert enkelt læg med I.J.N., man skrevet med lille begyndelsesbogstav ${ }^{13}$ ), rigelig men ikke overdreven anvendelse af bindestreger ${ }^{14}$ ), enkelte understregninger ${ }^{15}$ ), og - som de sikreste - ligeligt forhold mellem lodret og vandret dimension $i$ skrifttrækken $\mathrm{e}^{18}$ ) og slanke storbogstaver ${ }^{17}$ ). Alt vel overvejet, er der ingen af de materielle kriterier der vælter den datering vi nåede til ud fra indre - og værdifuldere - grunde.

$\mathrm{Vi}$ er dermed nået til teksten selv, som vil blive aftrykt bogstavret - lige til den lille streg under overskriften, som vi også finder i Danne-Virke-afhandlingen dog således at eventuelle fejl berigtiges med oplysning om foretagen rettelse. Gr.s egne overstregninger vil blive oplyst i noter, med mindre det drejer sig om rene, af ham selv rettede fejl (heri indbefattet gentagelser) eller om ikke fuldskrevne ord uden betydning for sammenhængen. Flere af de strøgne ord er særdeles oplysende, således at han først har kaldt sig selv en »middelmaadig« student, men alligevel har kviet sig ved denne for ærlige betegnelse.

Om mit Forhold til det antiqvariske Studium.

I det jeg atter sætter Foden paa en Bane, jeg i lang Tid ei egenlig betraadte, er det neppe af Veien, at melde $\mathrm{et}^{18}$ ) Ord, saavel om mit forrige, som om mit nærværende Forhold til den og til det antiqvariske Studium.

af sangen til Abr. Kall 2/7 1817 (fasc. 388 nr. 27). Efter en pause fra 1825 bliver det igen almindeligt fra 1828 .

$\left.{ }^{12}\right)$ Jf. NTBB 1946. 116 f. og Albeck GrStud. 1949. 80 noten. På papirer bestemt for fremmede (heri ikke medregnet trykkeren af DV) mangler eller formindskes bogstaverne dog tidlig.

13) Som ung skriver Gr. ordet med stort. Fra og med DV indføres lille begyndelsesbogstav (undt. dog den utrykte afhandling fra 1822 om Ingemann, fasc. 175) for igen at afløses af stort $M$ ved slutningen af 1830.

14) Gennemført fra 1816 (jf. NTBB 1946. 120), evt. allerede 1815.

$\left.{ }^{15}\right)$ Svarer til spatiering i trykkene. Tilstedeværelse af understregning tyder på at trykning overvejes. I 30erne og 40erne tager det så voldsomt overhånd at stregerne må opfattes som betoningstegn.

$\left.{ }^{16}\right)$ Dette er typisk for den sidste hlavdel af 1810erne, men findes mere eller mindre udtalt fra 1810 til 1830 , i 1820erne dog med stedse tiltagende vandret dominans (lodret dominans før 1810).

${ }^{17}$ ) Sxrlig typisk er den nederste del af B, S og T. Forandringen til det bredere fuldbyrdes 1823 .

19) Herefter overstr. Par. 
Man veed, at fordum ansaaes dette Studium for en Deel af ${ }^{19}$ ) Philologien, og egenlig for dens Handlanger ved Opførelsen af grundmurede Commentarer paa classiske Tofter; men $\mathrm{i}$ den Forstand har jeg aldrig enten yndet eller drevet det, da jeg af Naturen har Modbydelighed for alskens Hakkemad og Billingkram, og heller aldrig har kunnet forstaae, hvi de gamle Hedninger, især de tvære, frosne Romere skulde være saaledes i Vælten, at man maatte giøre sig en Fre af at løse deres Skobaand og slikke Støvet op under deres Fødder. Fra Barndommen af stirrede jeg kun med dyb Frbødighed paa Herrens Folk i Palæstina og i Kirken ${ }^{20}$ ), og med inderlig Kiærlighed paa Fædre og Frænder i det gamle Norden, ja end ikke her følde jeg Lyst til noget Pillerie, men Storheden i det Hele og Enkelte, den vidunderlige Sammenhæng mellem Himlen og Jorden, og Heltenes Slægter, II (1 v) det var, hvad der greb og begeistrede mig. Imidlertid, hurtig forløb de herlige Aar, i hvilke Aand $^{21}$ ) er os, saa at sige, naturlig, jeg opvoxde i et Tidsrum, da intet Udvortes nærede, men Alt stræbde at slukke Videnskabeligheds ædlere Gnist, jeg anklager ingenlunde mine Lærere, Gud ske Lov for dem jeg fik! Ingen kan jeg nævne, som jeg heller vilde havt, jeg klager ikke over nogen udvortes Omstændighed, thi jeg veed, at Gud fører ethvert Menneske ad de gavnligste Veie, og jeg indseer ydermere, at det Bedste der dengang kunde times mig, var at jeg indslumrede; men jeg siger det kun, fordi det er sandt: Ingen af mine Lærere forstod sig paa mig, da de ellers uden Møie kunde gjort mig til en Student, der i historisk og philologisk Forstand skulde ledt om sin Mage. $\mathrm{Nu}$ derimod vandes jeg til at ansee min historiske Drift og min Kiærlighed til Oldtiden for naturlige Tilbøieligheder, som det ei gik an at følge, og med Ulyst giennemløb jeg det academiske Cursus, som Noget, der paa ingen Maade stod i Forbindelse med den Videnskabelighed, jeg fra Barnsbeen havde elsket, og som stedse, i en dunkel, indtagende Skikkelse svævede mig for Øie. Mine Universitets-Aar, som saadanne, kan jeg aldrig uden Harme komme ihu, ingen Professor, som saadan, har jeg det Mindste at takke, $\left.{ }^{22}\right)$ den nymodens II (2 r) Tænkemaade over Religion, Stat og alt Saadant, der uden at være mig ubekiendt $\mathrm{i}$ min Opvext, var mig en Vederstyggelighed, lige til jeg deponered $e^{23}$ ), lærde jeg snart at tilegne mig, men derfor kan jeg hverken rose eller laste Nogen, uden mig selv, thi det faldt af sig selv, og det tørre, mechaniske, kiedsommelige, aandløse, aandsdræbende Foredrag, som dengang herskede, hvor jeg kom, lærde jeg aldrig at forsone mig med. At det maa være slet bestilt med Videnskabelighed i en Tid, da en saa letnem Ungersvend med særdeles Smag paa Læsning, og uden ${ }^{24}$ ) nogen stærk $^{25}$ ) Tilbøielighed til Andet end Bøger, uden paa nogen Maade at indhvirvles i Verden, naar han netop paa Høiskolen, staaer Fare for at glemme Videnskaberne, og henfalde til Sludder-Læsning for Tids-Fordriv, det mener jeg er saa klart, at blot et eneste saadant Exempel burde vække dem der have paa og med Høiskoler at giøre, til nøie at undersøge og betænke, hvorvidt

19) Herefter overstr. Philol den classiske.

$\left.{ }^{20}\right)$ De tre sidste ord tilføjet over linjen.

21) Rettet fra Aanden.

22) Herefter overstr. og jeg maa være glad ved den tørre, mechaniske.

23) ว: blev student.

$\left.{ }^{24}\right)$ Herefter overstr. at lade sig adsprede eller hen.

25) Rettet fra herskende. 
$\left.\mathrm{de}^{28}\right)$, ogsaa i deres nærværende Skikkelse, svare til deres store Bestemmelse. Kun derfor siger jeg det ogsaa, thi for min Skyld kan det være det Samme, det er forbi, og jeg er vis paa, at mig timedes alligevel det Tjenligste, for andre Unges Skyld siger jeg det egenlig ikke heller, thi hvor der er Noget inde, som skal frem, der finder det nok Udvei, men Enhver skylder || (2 v) Regnskab for sin Medvirkning, og har, om han forsømmer den, i alt dette ei mindste Undskyldning. Hvad der udvortes reddede mig, var, som jeg før ${ }^{27}$ ) har sagt, og aldrig kan glemme, det, efter Talebrugen tilfældige, Bekiendtskab, der i Anledning af Studenter-Væbningen ${ }^{28}$ ) timedes mig med Bornholmeren P. N. Skougaard, en Mand der syndes skabt til de største Polyhistorers lykkelige Medbeiler, og hvis sandsynlige $\mathrm{Tab}$ for $^{29}$ ) det antiqvariske Studium jeg høit vilde bebreide Omstændighederne, dersom jeg ikke vidste, at selv trods alt Skin, ere Omstændighederne dog i Grunden Intet uden viselig sammenkiædede Ringe, der kun binde hvad der ei maa løses. Ingenlunde lærde dette Bekiendtskab mig at forbinde min academiske Bane med min videnskabelige Drift, det bestyrkede mig snarere $\mathrm{i}$ den Troe, at derimellem var et unedbrydeligt Skillerum, og hvad havde heller i Grunden hine Dages Theologie med Historien at giøre! men jeg fik dog et Menneske, med hvem jeg kunde tale om hvad jeg elskede, uden at besvares med Latter eller Skuldertræk, jeg fandt en Jævnaldrende, som var langt forud for mig i Kundskaber, som alt var en gammel Ven af Edda, Saxo og Snorro, som læste Islandsk og Runer, som kunde sige mig hvor der var Noget at hente, som førde mig op paa RundeTaarn for \|| (3 r) Andet end at gabe, kort sagt en virkelig Privat-Præceptor. Hvilken underlig Brændpunkt der for Nordens Børn maa være i FædreneLandets Historie, lod sig her ret til Syne, thi saa forskiellige som det vel er mueligt, vare min Ven og jeg i vore videnskabelige Synsmaader, han var Mathematiker med Liv og Sjæl, og jeg netop det Modsatte, men heraf fulgde ogsaa, at uagtet jeg var grov nok til at stjæle Tid fra Attestatsen, anvendte jeg den dog ikke til flittigt antiqvarisk Studium, men kun til at more mig med de gamle Bøger og Forestillinger, for hvilke jeg, uden at ahne det, havde langt mere poetisk end videnskabelig Kiærlighed, og stræbde derfor at tilegne mig, under Skrivning af Fortællinger i Suhms og Samsøes Smag, og i Dialoger, med Dyveke for Øie. Vel var det, at Omstændigheder hindrede mig fra, at komme frem med Sligt, men nu kunde jeg snart faae i Sinde at give Noget deraf til Priis, for at lære Folk, at jeg ogsaa i dette Stykke ret god veed, hvad jeg bryder Staven over. Efter lykkelig at have faaet Attestatsen paa Ryggen, begyndte jeg, borte fra Byen, og uden al Veiledning, at lære Islandsk, prøvede, i Sommeren 1804, forgiæves paa at vinde Fodfæste i Hovedstaden, og nødtes da til, som Ludimagister ${ }^{30}$ ), at drage til en af de mest uvidenskabelige Egne i Øst-Dannemark. Her, hvor || (3 v) saa at sige, Staal og Steen gav Ild, begyndte der at opgaae et Lys for mig, over Grunden til min dunkle Drift, og over Sammenhængen mellem Poesie og Videnskabelighed, Anskuelse og Granskning, og her er det, jeg efterat have lyttet i Stilhed enstund til Oehlenschlägers og Shakspears, Ossians, Gøthes og Schillers Har-

$\left.{ }^{26}\right)$ Herefter overstr. i deres.

${ }^{27}$ ) I fortalen til Nordens Mytologi 1808, s. XVII fodnoten (US. I. 251, VU.I. 153).

${ }^{28)}$ Den indkaldtes 28. marts 1801, jf. Rønning. N.F.S. Grundtvig I.1.26f.

$\left.{ }^{29}\right)$ Herefter overstr. Nordens.

30) Gr. ankom til Egeløkke som huslærer i marts 1805. 
per, grublet med Fichte og Schelling, og lært ${ }^{31}$ ) halvveis at forstaae, hvad der fordum om Poesie og Historie klang eventyrlig for mig fra Steffenses Laber, betraadte Forfatter-Banen som nordisk Mytholog. Jeg kan ikke sige, at jeg giorde det frygtsom, thi fortroelig med boglig Konst fra Barnsbeen, og vant ti ${ }^{32}$ ), fra Drenge-Aarene, at tale som jeg tæenkde, og skrive som jeg talde, havde jeg ligesaalidt ${ }^{33}$ ) Begreb om at være bange for at skrive, som for at tale offenlig, og naar man kun veed, hvad man vil sige, og troer det kan lade sig høre, maa den Ting vel ogsaa gaae af sig selv. I mine yngre Dage, naar jeg tænkde paa Forfatterskab, spurgde jeg mangengang mig selv: hvad har du at sige, som ikke alt vel hundrede Gange er bedre sagt, og saa hængde jeg med Næsen, og lod den Fugl flyve; men nu følde jeg, at jeg havde Noget at fortælle, som Ingen havde sagt mig, derfor lod jeg Pennen gaae og Bladet flyve; II (4 r) men, vel bekiendt med Omfanget af et Studium, hvis Enemærker jeg havde overfaret, altsaa vel underrettet om hvad jeg fattedes, og uden Leilighed til at bøde paa Savnet, ansaae jeg mine Blik paa Nordens Oldtid hardtad som stjaalne Blik paa en Andens Brud, som man slet ikke tænker Nogen lægger Mærke til, men ønsker blot maae taales. Først da Skougaard, som jeg tænkde var den, der mindst vilde bryde sig om slige Overblik, fra det Fjerne lod mig vide, at han og flere Oldtidens Venner havde frydet sig ved Glimtene, fattede jeg Mod til at troe, det Forsømte lod sig endnu indhente, ved Professor Nyerups Godhed ${ }^{34}$ ) voxde mine Hjelpemidler, og $\mathrm{med}^{35}$ ) levende Begeistring studerede jeg. Endelig kom jeg atter til Hovedstaden - 1808 - og denne Gang lykkedes det mig at faae Fodfæste, dog ikke anderledes, end det sædvanlig kan lykkes en ung ${ }^{36}$ ) Student, der, som Time-Lærer vil æde sit Brød i sit Ansigts Sveed. Jeg skrev min Mythologie, som $i$ det Hele Ingen herinde brød sig om, af Opmuntringer skal jeg paa min hele Bane ikke rose mig, ${ }^{37}$ ) Forliebelse i en Gienstand, der ei agtedes synderlig, som ikke næredes, men bekiæmpedes af Omstændighederne, og havde været baade for sværmerisk og eensidig, til at bære sig selv, lunknedes efterhaanden saavidt, at jeg opgav Studiet, og morede mig kun med Beskuelsen af Kæmpelivet i Valhals Glimmer-Skygge. II (4 v) Denne Gang var jeg da virkelig nær ved at have blevet nordisk Antiqvar for ramme Alvor, men der blev Intet af, og vel var det, thi hvad kunde det nyttet, om jeg ved fortsat Studium, hvad Tiden har viist under heldigere Omstændigheder vilde skeet, havde hjulpet til at indtage de Yngre for en halvklog, men just derfor ogsaa halvgal Beskuelse af Oldtiden og Modersmaalet! Naturligviis var det min alvorlige Beskixftigelse med Universal-Historien, hvori jeg var Lærer, som saare meget bidrog til at dæmpe Asa-Rusen, og minde mig om hvad Tiden langt anderledes trængde til, end til bedre Forstand paa Oldtidens Myther og Frasagn; vist nok havde jeg stedse betragtet Valgrind, som hvad den havde været for mig, Dørren til Sagas Tempel, hvor Alter-Tavlen

31) Herefter overstr. omtrent.

32) Herefter overstr. fra jeg kunde male Kragetæer, at skrive som jeg tænkde og talde -.

33) Rettet fra har jeg aldrig havt noget.

34) Ved som overbibliotekar ved Universitetsbiblioteket at tillade rigeligt udlån til Egeløkke af nordisk-mytologisk litteratur (jf. Rønning. I. 2.4).

$\left.{ }^{35}\right)$ Herefter overstr. den mest.

${ }^{36}$ ) Herefter overstr. , middelmaadig.

${ }^{37}$ ) Herefter overstr. klart indsaae jeg endnu ikke. 
hængde bekrandset med vidnesføre Kiærminder, men deels mærkede jeg, at neppe mange vilde færdes paa den Vei, deels begyndte jeg at indsee, at Dørren førde til to Gemakker, langt mere forskiellige, end jeg hidtil havde ændset: til Eventyrets saavelsom til Historiens, og endelig slog det mig, at selv ved en christelig Beskuelse var Intet uden Blændværk vundet, naar Troen fattedes. Nu var det mig, for min egen Skyld nødvendigt, at lade Nordens Oldtid staae ved sit Værd, redde mig i Kirkens, og opbyde Alt, for at drage Andre did, hvor der var Rum saavel for Læg som Lærd, og hvor den eneste sande Redning var for En og Hver. II

(5 r) At man ansaae min Præste-Tale for Galskab, det var i Grunden intet Under, og man spørge kun Athene og vore baade poetiske og philosophiske Grønskollinger ad, saa skal man høre, at de, i mit Sted, hvor de nok gad været, havde vidst en langt mageligere og mere blomstrende Vei til at finde Livets Betydning, men alt det vil jeg her gaae forbi, da det kun er det jeg vil sige: hvorledes og hvordan jeg atter er kommet tilbage til det antiqvariske Studium.

Om det Første kan jeg fatte mig kort, thi hvem der ønsker at kiende min Bane, læser mine Skrifter; og finder da strax, at jeg giennem Historien, som jeg aldrig skiød fra mig, er kommet, og maatte nødvendig komme did; men hvordan jeg er kommet der $\supset$ : i hvilket Lys jeg betragter dette Studium, lader sig vel ikke saa lige indsee.

At jeg nu, ligesaalidt som før, lægger nogen Vægt paa gamle Aske-Potter, som smuldre saasnart man rører dem, og paa alt det Snurre-Piberie, man har gjort Væsen af, og derved virkelig gjort Nordens Oldtid til en Carricatur af den græske og romerske, hvis underjordiske og i det Hele sandselige Mindesmærker forholde sig til vore, som et Marmor-Tempel til et Kampesteens Grav-Kammer; det vil man udentvivl formode; men finde sig skuffet, som i saamangen Formodning om mig. At jeg aldrig i noget Studium kan giøre Handvark til Hovedsag, det følger af sig selv, men af sund Eftertanke følger || (5 v) ogsaa Intet at forsmaae, som i Historien kan tjene til Oplysning, og at holde Hævd selv over de ubetydeligste Levninger fra en Tid, som ingen større har efterladt i kiendelig Skikkelse. Veed man det, saa veed man meer, veed at jeg nu tilfulde sætter Priis paa mangen Mythe, og mangt et Vink, som jeg før ringeagtede, og hardtad hadede, fordi mig syndes, tit neppe uden Føie, at det var senere Opdigtelser, som vanhældede og fordærvede ældre, høiere og adlere Forestillinger, men hvad da! de tilhøre og oplyse dog ogsaa en Tid som ligger bag os, de afbilde ogsaa Træk i den gamle Nordboes Aasyn, som det er Vinding for os at kunne betragte, som Tid og Flid nok vil anvise sit rette Sted og Forhold, og som man da nødig skulde undvære. Hvad jeg nu som altid elsker og skatter, er vist nok ikke Kundskaben som et Hukommelses-Værk, men den skjulte Kierne: Grunden til, Udviklingen og Betydningen af det Hele; men jeg har ikke længer Hastværk af det Slags som før, det er mig ikke om et System at giøre, thi vi skal jo ikke være Einherier, og et System, hvis Blomstrings-Tid vi ei kan bestemme er os da, historisk talt, ei til synderlig Nytte; og komme vi ikke i Dag, saa komme vi i Morgen, og jo sagtere vi gaae, des mindre oversee vi paa Veien. Det falder vel neppe Nogen ind, || (6 r) at jeg hermed vil frakiende Nogen Ret til at bruge sine Øine, som han bedst kan, og sige hvad han seer, eller at jeg troer noget Studium, end sige da det antiqvariske kan lykkes, uden $a t^{38}$ ) vel agte paa,

38) Tilføjet her, mgl. i ms. (ved linjeskifte). 
hvad dristige Øine have seet eller skimtet; nei den Muldvarpe-Troe at man arbeider bedst paa Videnskaberne i Blinde, bliver aldrig min, og kan saameget mindre blive det, som det altid har været mig umueligt at arbeide for alvor paa den Maneer; men selv de bedste Søndags-Glugger ${ }^{39}$ ), med Kiød-Hinden for, $\left.{ }^{40}\right)$ maae kun veilede, ingenlunde binde eller tøire Haanden, og eftersom Syn er nutildags, maa man have et Øie paa hver Finger, om man ikke, under Troen paa sine egne Øine, skal løbe efter Næsen. Man kan i den nærværende Tid ei noksom anspore de letnemme Unge til Flittighed og grundigt Studium, thi Flagren, og Spillen med gamle Billed-Gienfærd i Maaneskin, er hvad det nittende Aarhundredes Børn fristes og lettelig henfalde til; vor Tids Poesie er en Billedbog stukket efter Historien, og illumineret med electriske Farver, der giver lette behagelige Stød, som den Unge gierne anseer for Begeistring, og stræber at forplante i Efterligning eller Commentar, eller dog at vedligeholde, og dette, i Forbund med, den Magelighed der er Slægten paa sine gamle Dage, selv hos || $(6 \mathrm{v})$ de Unge, naturlig, lader virkelig befrygte, ikke at vi skal blive et Folk af Poeter, men at Videnskabelighedens faste Stok skal udarte til en Flok, i deres egne Øine, klarseende Drømmere, der hverken have Lyst eller Kraft til alvorlig og stadig Flid og Granskning. Vil vi saaledes giennemløbe Rakken af de ikke faa fyrige, og tildeels vel begavede Ungersvende, der, siden 1807 have ladet sig høre, og vi skal ikke finde en eneste, $\operatorname{der}^{41}$ ) med et bedre Syn for aandige Skikkelser, forbandt Attraa efter grundige Kundskaber, eller befattede sig med Andet, end hvad man omtrent kan sove sig til. Moderne Digte, Esthetiker, og stundum philosophiske Bøger, er aabenbar det Eneste, de paa en Maade er hjemme i, Digtere, Philosopher, eller allenfalds Esthetikere vil de alle være, og da nu selv de virkelige Genier i vore Dage, uden alvorligt Studium snart udtømme sig, hvad maa der da blive af de andre! Det er let at sige: naar de have sagt den Smule de veed, naar den Brusen de tog for Begeistring standser, da ligge de der, for det Meste uduelige til enhver ordenlig Bestilling, men i al Fald, for det Meste uigienkaldelig tabte for den Videnskabelighed, der vilde styrket, udviklet og glædet dem, medens de kraftig og hæderlig fremmede den; og var det ikke da en stor Ulykke og Fordærvelse, om det Sløserie skulde tage \| (7 r) Overhaand, og Videnskabeligheden nøies med dem til Tjenere, der netop fik Nemhed nok til at lære endeel Kundskaber udenad, og Hoved nok til at slaae Yngre over den samme Læst, de sloges selv! Vore Frisk-Fyre synes at finde et Slags Forsvar i det forrige Aarhundredes Lærde, der, med al deres Kundskab, ingen Vei kom; men de glemme, at en af de vigtigste Grunde dertil netop var, at næsten alle de bedste Hoveder vilde være Digtere eller Philosopher, og ikke stort andet, og at det for dem selv gik an som det gik, kom deels af, at man ikke var kræsen, deels deraf, at de dog for det Meste i den første Ungdom havde indsamlet en ganske anderledes Skat af Kundskab, end det siden blev Skik.

Dog, dette vilde jeg her kun pege paa, $\mathrm{og}^{42}$ ) vender tilbage, ved at erindre, at indrømmer jeg end ikke Nogen Ret til, efter et Kiæde-Syn af Mythologien, eller hvad det saa i Fortiden er, at vrage det Mindste, eller videnskabelig beslutte Noget, asalænge der er en eneste Indsigelse, han ei grundig kan

$\left.{ }^{39}\right)$ Rettet fra Søndags-Øine.

40) Herefter overstr. m skal end sige da ma (åbenbart et par tilløb til maa).

${ }^{41}$ ) Herefter overstr. enten viiste Fortr.

42) Herefter overstr. jeg. 
besvare, en eneste Anstøds-Steen der ei passer i Bygningen, da maa jeg naturligviis af al Magt modsætte mig dem, der fra den anden Side, uden Syn for det I| (7 v) Hele og Indvortes, klæbende ved det Enkelte, og smagende paa Skallen, vil forklare eller afgiøre det Allermindste ${ }^{43}$ ). Ethvert Lands selvgjorde Oldsagn ere jo Brudstykker af en styrtet Bygning, mange saadanne har Tiden opløst, og nu at ville forklare et saadant af sig selv, eller sammenligne det, som saadant med hvad der udenlands kan være ligt, er saameget des daarligere, som vi aabenbar see, at de bekiendte Folk for en stor Deel havde Fyldingen tilfalleds, saa det egenlig $\mathrm{er}^{44}$ ) Samlingen og Stilen hvorom det gixlder. Hvad kommer vel derudaf at man, saaledes, kan finde Lighed mellem et enkelt Sagn om Odin og et om Budha, ja hvad kom der ud af, om man endog kunde finde Lighed i Alt hvad vi nu veed om dem, naar vi ikke først kiende hver i sit bestemte Forhold! Hvad kunde det hjelpe, om vi ogsaa ${ }^{45}$ ) fandt en Ramme, hvori hele Nordens Mythologie kunde udvortes passe, naar vi dog ikke vidste, om Nordboen ogsaa virkelig havde meent det saa, kort sagt, naar vi ei kan forbinde de mythologiske og historiske Sagn, saa de giensidig stadfæste og forklare hinanden!

Bagfra har man da begyndt det antiqvariske Studium, og det Hele maa i alle \| (8 r) Maader begyndes forfra, om det skal lykkes, om Oldtiden ikke, som hidtil skal være en aaben Boldgade for Enhver, som vil giøre Løier, en Markeds-Plads for Enhver, som vil føre sit Vid, sine ${ }^{46}$ ) Indfald, eller Kundskaber ${ }^{47}$ ) til Torvs, og skulde det saaledes vare ved, da maatte vi heller, som Schlötzer og Rühs ${ }^{48}$ ), lade Kirke-Muren giøre Skiel mellem den historiske og den fabelagtige Tid, og, uden at bryde os videre om denne, lade Digteren husere der, som han lystede. Men det behøves ingenlunde, og bør da ikke heller skee, Intet er skjult, som jo engang maa aabenbares, og vi kan godt forstaae, hvorledes det efterhaanden maa skee, naar man lukker sine Øine op, arbeider flittig og bruger sin Forstand. Lære vi først at kiende Folkene i deres klareste Dage, og komme til den simple Forstand, at hvad der blev en Daler var ikke slaaet til en Skilling, og overalt, at hvad der kommer ud har været inde, og at hvad der var inde maatte engang komme ud, da vil vi alt kunne stave os et godt Stykke tilbage, og i det Mindste see, hvad der er ved || (8 v) Omridset at giøre, hvad der omtrent kan have hjemme, hvor det findes, og hvad der aabenbar forskriver sig andenstedsfra. Har vi nu først gjort det med ethvert af de bekiendte Folk, da er det Tid at sammenligne, og at sammenlæage de smaa Vink, der ingenlunde fattes, og da hitter man sikkerlig Rede i det Meste. Man seer da let, at før det antikvariske Studium kan komme ret i Gang, og efterhaanden videnskabelig løse de store Spørgsmaal om Folkenes Oprindelse og Sammenhæng, maa man grundig studere ethvert Folks nyere Sprog og Historie, dyrke de gamle Sprog med

43) Herefter overstr. ; thi saameget er vist, at hvad vi finde, saa at sige, nagelfast.

${ }^{44}$ ) Herefter overstr. Bygnings.

45) Herefter overstr. havde.

48) Herefter overstr. Hypotheser,

$\left.{ }^{47}\right)$ I ms. står Kundskabs med forudgående overstr. sin Sprog -.

${ }^{48}$ ) Herefter overstr. skiære reise en Muur. 
Iver, og omhyggelig samle alle Oldtidens Levninger ${ }^{48}$ ). Hypotheser om Sammenhængen ere naturligviis enhver uformeente, men enten de fremsættes $i$ Vers eller Prosa, blotte eller understøttede med udbredt Læsning, maae vi aldrig glemme, at de ere enten Slag i Luften, eller poetiske Gixtninger, de første ændse vi ikke, de sidste skrive vi bag Øret, men ansee derved Intet for afgjort.

49) Betyder for Gr. levninger af digtning etc., jf. B. C. Sandvigs Levninger af Middel-Alderens Digtekunst (1780-84). 